\title{
ANALISIS PERAN DAN FUNGSI PENGAWASAN KPID SULAWESI TENGAH TERHADAP KEBIJAKAN PROSES SIARAN DI KOTA PALU
}

\author{
Suhayat Panji Putra, Muhammad Khairil \\ Program Studi Ilmu Komunikasi FISIP Universitas Tadulako \\ Email:suhayatpanji945@gmail.com
}

\begin{abstract}
ABSTRAK
Melalui peraturan yang tercantum dalam UU No. 32 Tahun 2002 tentang tentang Penyiaran, maka Komisi Penyiaran Indonesia Daerah (KPID) Sulawesi Tengah memiliki tugas, kewajiban dan wewenang yakni sebagai regulasi atau pengaturan serta pengawasan dan pengembangan. Penelitian ini bertujuan untuk mengetahui pengawasan yang dilakukan KPID Sulawesi Tengah terhadap Lembaga Penyiaran di kota Palu. Metode penelitian yang digunakan adalah kualitatif dengan menggunakan metode purposive sampling. Teknik pengumpulan data pada penelitian ini berupa observasi, wawancara dan dokumentasi berupa dokumen-dokumen yang menunjang penelitian. Hasil penelitian menunjukkan bahwa fungsi pengawasan KPID Sulawesi Tengah terhadap kebijakan proses siaran di kota Palu ialah; (1) bekerja sama dengan KPU dan BAWASLU dalam pengawasan siaran kampanye, dan kepolisan sebagai instansi dalam penindakan lebih lanjut terkait dengan pelanggaran yang dilakukan; (2) menggunakan P3SPS sebagai Rule atau pedoman dalam melakukan pengawasan untuk menilai pelanggaran-pelanggaran yang dilakukan Lembaga Penyiaran di kota Palu; (3) melakukan pengawasan langsung Lembaga Penyiaran yang disiarkan; (4) menerima keluhan-keluhan terkait penyiaran dari masyarakat.
\end{abstract}

Kata Kunci : KPID; Pengawasan Siaran; Radio; Televisi

Submisission: 26 April 2021

\section{Pendahuluan}

Media penyiaran merupakan sebuah organisasi yang mempunyai fungsi untuk menyebarkan informasi yang berupa produk budaya atau pesan yang mempengaruhi dan mencerminkan budaya dalam masyarakat. Oleh karena itu, seperti halnya politik atau ekonomi, media penyiaran merupakan suatu sistem tersendiri yang merupakan bagian dari sistem kemasyarakatan yang lebih luas (Morrisan, 2008).

Fungsi penyiaran dalam Undang Undang Republik Indonesia Nomor 32 Tahun 2002 (2015:7) pasal 3 Tentang
Penyiaran yaitu penyiaran diselenggarakan dengan tujuan untuk memperkukuh integrasi nasional, terbinanya watak dan jati diri bangsa yang beriman dan bertaqwa, mencerdaskan kehidupan bangsa, memajjukan kesejahteraan umum dalam rangka membangun masyarakat yang mandiri, demokratis, adil dan sejatera, serta menunumbuhkan industri penyiaran Indonesia. Sedangkan dalam pasal yang ke 4 menyatakan Penyiaran sebagai kegiatan komunikasi massa mempunyai tugas sebagai media inforamsi, pendidikan, hiburan yang sehat, kontrol dan perekat sosial (Eli Fatmala, 2018). 
Salah satu dampak yang ditimbulkan yaitu masuknya nilai-nilai asing secara sadar ataupun tidak sadar yang telah memberi pengaruh langsung maupun tidak langsung kepada masyarakat. Media penyiaran dalam mengemban tugas sebagai penyebar informasi, pewarisan nilai-nilai budaya, mendidik, menghibur, kontrol sosial, harus dapat menyampaikan pesan agar masyarakat dapat memperoleh informasi yang jelas, lengkap, jujur, beretika, dan bermoral serta objektif (Unde, 2014 : 35). Oleh karena itu dalam menayangkan siarannya lembaga penyiaran dipantau oleh KPI (Komisi Penyiaran Indonesia) yaitu lembaga Negara yang berperan dalam mengawasi pelaksanaan penyiaran yang ada di Indonesia. Dan sebagai rangkaian dari lembaga-lembaga pemerintah yang memiliki banyak komponen organisasi dengan berbagai kewenangan yang satu sama lain berbeda namun saling berhubungan (Samad, 2014).

Kemajuan teknologi satu sisi telah berhasil mengatasi keterbatasan jarak dan waktu yang cepat, tetapi disisi lain mempertajam ketidakseimbangan arus informasi. Kemajuan teknologi ini juga telah dinikmati oleh banyak masyarakat Indonesia. Khususnya di bidang komunikasi. Hal ini dinikmati melalui radio, televisi, film, dan surat kabar. Bahkan seluruh pelosok Indonesia dapat menikmati kemajuan teknologi tersebut (Jueita, 2013).

Sebagai lembaga negara yang berperan dalam mengawasi pelaksanaan penyiaran di Indonesia, Komisi Penyiaran Indonesia mempunyai wewenang untuk melakukan teguran terhadap lembagalembaga penyiaran yang menampilkan program acara yang tidak layak untuk dipertontonkan atau didengarkan oleh masyarakat. Agar terciptanya tayangan yang berkualitas sebagaimana yang tertuang dalam Undang-Undang No 32
Tahun 2002 tentang Penyiaran, Komisi Penyiaran Indonesia dibantu oleh Komisi Penyiaran Indonesia Daerah. Komisi Penyiaran Indonesia Daerah dibentuk berdasarkan amanah Undang-Undang Nomor 32 Tahun 2002, Komisi Penyiaran Indonesia terdiri dari Komisi Penyiaran Indonesia pusat, di bentuk tingkat pusat dan Komisi Penyiaran Indonesia Daerah, KPID dibentuk pada setiap tingkat provinsi.

Dengan adanya KPI (Komisi Penyiaran Indonesia) dan KPID (Komisi Penyiaran Indonesia Daerah) yang merupakan lembaga Negara yang berperan dalam mengawasi system penyiaran nasional dan daerah, dengan harapan agar terciptanya ilklim penyiaran yang baik diseluruh wilayah indonesia, dengan melihat pada Pedoman Perilaku Penyiaran dan Standar Program Siaran (P3SPS) sebagai acuan dalam menjalankan tugasnya, dengan adanya P3SPS para pelaksana penyiaran mempunyai batasan-batasan dan aturan baik maupun buruk dalam menayangkan siaranya.

Dalam rangka menjalankan fungsinya KPI memiliki wewenang (UU penyiaran Pasal 8) menetapkan standar program siaran, menyusun peraturan dan menetapkan pedoman prilaku penyiaran, mengawasi pelaksanaan peraturan dan pedoman prilaku penyiaran serta standar program siaran, memberikan sanksi terhadap pelanggaran peraturan \& pedoman prilaku penyiaran serta standar program siaran, melaksanakan koordinasi dan kerjasama dengan pemerintah, lembaga penyiaran dan masyarakat (Prasetyo, 2017).

Seperti halnya dijelaskan diatas sehingga diketahui bahwa betapa pentingnya pengawasan yang di lakukan oleh KPID Sulawesi Tengah amat diperlukan apalagi bagi lembaga penyiaran lokal yang berada di Sulawesi Tengah terkhususnya di kota Palu 
tentunya sangat diharapkan untuk mengutamakan program yang menyajikan siaran yang baik dan sehat, agar terciptanya siaran yang sehat dan berkualitas bagi masyarakat kota Palu dengan tetap berpegangan pada budaya dan norma-norma yang berlaku di masyarakat.

Dibalik siaran berkualitas yang ditampilkan oleh Radio dan Televisi di kota Palu ada peran serta KPID Sulawesi Tengah dalam mengawasi sistem penyiaran sesuai dengan pedoman perilaku penyiaran dan standar program siaran, yang menjadi fokus pada penelitian saat ini adalah bagaimana KPID Sulawesi Tengah menjalankan peran dan fungsinya dalam pengawasan terhadap kebijakan proses siaran di kota Palu, agar siaran yang disaksikan oleh masyarakat menjadi siaran yang sehat dan berkualitas. Berdasarkan dari pemikiran tersebut peneliti tertarik untuk mengkaji bagaimana peran dan fungsi pengawasan KPID Sulawesi Tengah terhadap kebijakan proses siaran di kota Palu, dengan melihat KPID Sulawesi Tengah sebagai lokasi penelitan.

\section{Tinjauan Pustaka \\ Penyiaran}

Undang-Undang Nomor 32 tahun

2002 menjelaskan bahwa penyiaran adalah kegiatan pemancaran secara luas siaran melalui sarana pemancar dan atau sarana transmisi di darat, laut atau antariksa, dengan menggunakan spektrum frekuensi radio, melalui udara, kabel dan atau media lainnya, untuk dapat diterima secara serentak dan bersamaan oleh masyarakat dengan penerimaan siaran. Penyiaran pada hakikatnya salah satu keterampilan dasar manusia ketika berada pada posisi tidak mampu untuk menciptakan dan menggunakan pesan secara efektif untuk berkomunkasi. Penyiaran dalam konteks ini adalah alat untuk mendongkrak kapasitas dan efektivitas komunikasi massa.(Mufid, 2010 : 19). Dunia penyiaran yang semakin maju dengan berbagai program siaran baik diswasta maupun lokal, maka penyiaran perlu adanya pengawasan dari suatu lembaga penyiaran itu sendiri agar menciptakan siaran yang berkualitas (Rolando, 2018).

\section{Regulasi Penyiaran Di Indonesia}

Beberapa aturan yang terkait dengan program siaran yang tercantum dalam Undang-Undang Penyiaran dapat dikategorisasi dalam bentuk "kewajiban" dan "larangan" terhadap isi siaran. Terdapat empat kewajiban isi siaran bagi lembaga penyiaran dalam menyampaikan program siarannya, yaitu: (1) Isi siaran wajib mengandung informasi, pendidikan, hiburan, dan manfaat untuk pembentukan intelektualitas, watak, moral, kemajuan, kekuatan bangsa, menjaga persatuan dan kesatuan, serta mengamalkan nilai-nilai agama dan budaya Indonesia. (2) Isi siaran dari jasa penyiaran televisi, yang diselenggarakan oleh Lembaga Penyiaran Swasta dan Lembaga Penyiaran Publik, wajib memuat sekurang-kurangnya $60 \%$ mata acara yang berasal dari dalam negeri. (3) Isi siaran wajib memberikan perlindungan dan pemberdayaan kepada khalayak khusus, yaitu anak-anak dan remaja, dengan menyiarkan mata acara pada waktu yang tepat, dan lembaga penyiaran wajib mencantumkan dan/atau menyebutkan klasifikasi khalayak sesuai dengan isi siaran. (4) Isi siaran wajib dijaga netralitasnya dan tidak boleh mengutamakan kepentingan golongan tertentu.

Sementara itu, terdapat beberapa larangan kandungan isi siaran yang tidak boleh disiarkan oleh lembaga penyiaran, yaitu dilarang bersifat fitnah, menghasut, menyesatkan, dan atau bohong, menonjolkan unsur kekerasan, cabul, perjudian, penyalahgunaan narkotika, memperolokkan, merendahkan, 
melecehkan dan atau mengabaikan nilainilai agama, martabat manusia Indonesia, atau merusak hubungan internasional (Judhariksawan, 2010).

\section{Pedoman Perilaku Penyiaran Dan Standar Program Siaran (P3SPS)}

Pedoman Perilaku Penyiaran ditetapkan oleh KPI berdasarkan pada peraturan perundang-undangan yang berlaku, nilai-nilai agama, norma-norma yang berlaku dan diterima dalam masyarakat, kode etik, serta standar profesi dan pedoman profesi yang dikembangkan masyarakat penyiaran.

Menurut KPI dalam Judhariksawan (2010) Pedoman Perilaku Penyiaran bertujuan agar lembaga penyiaran: (1) menjunjung tinggi dan meningkatkan rasa persatuan dan kesatuan Negara Kesatuan Republik Indonesia; (2) meningkatkan kesadaran dan ketaatan terhadap hukum dan segenap peraturan perundan undangan yang berlaku di Indonesia; (3) menghormati dan menjunjung tinggi norma dan nilai agama dan budaya bangsa yang multikultural; (4) menghormati dan menjunjung tinggi prinsip-prinsip demokrasi; (5) menghormati dan menjunjung tinggi hak-hak asasi manusia; (6) menghormati dan menjunjung hak-hak dan kepentingan publik; (7) menghormati dan menjunjung tinggi hak-hak anak, remaja dan perempuan; (8) menghormati dan menjunjung tinggi hak-hak kelompok masyarakat minoritas dan marginal; (9) menjunjung tinggi prinsip-prinsip jurnalistik.

Standar program siaran adalah panduan yang ditetapkan tentang batasanbatasan yang boleh dan tidak boleh ditayangkan pada suatu program siaran berdasarkan peraturan perundangundangan yang berlaku, nilai-nilai agama, norma- norma yang berlaku dan diterima dalam masyarakat, kode etik, standar profesi dan perilaku yang dikembangkan masyarakat penyiaran. Pedoman perilaku penyiaran adalah semacam kode etik penyiaran.

Sanksi yang dapat dijatuhkan oleh KPI hanyalah berupa sanksi administratif berupa: (1) Teguran tertulis, Penghentian sementara mata acara yang bermasalah setelah melalui tahap tertentu, (3) Pembatasan durasi dan waktu siaran, (4) Denda administratif, (5) Pembekuan kegiatan siaran untuk waktu tertentu, (6) Tidak diberi perpanjangan izin penyelenggaraaan penyiaran, (7) Pencabutan izin penyelenggaraan penyiaran.

\section{Pengawasan}

Menurut Handoko untuk menjadi efektif, sistem pengawasan harus memenuhi kriteria tertentu. Kriteriakriteria utama adalah bahwa sistem seharusnya mengawasi kegiatan-kegiatan yang benar, tepat waktu, dengan biaya yang efektif, tepat- akurat dan dapat di terima oleh yang bersangkutan. Semakin di penuhinya kriteria-kriteria tersebut semakin efektif sistem pengawasan(Luaylik, 2018).

Robert N. Anhony dan Jhon Deaden dalam Marhawati (2018) mengemukakan bahwa pengawasan (control) mempunyai empat elemen yaitu:

1. Detector, alat ukur untuk mengetahui apa yang terjadi terhadap parameter yang di kontrol.

2. Selector, alat untuk menilai apa yang terjadi dengan apa yang seharusnya terjadi

3. Effector, alat untuk merubah perilaku jika perlu untuk mencapai apa yang di inginkan.

4. Communication, menyampaikan informasi tentang semua hal yang di capai dan yang belum di capai dan upaya untuk mencapainya. 


\section{Radio}

Sejatinya terdapat beberapa media yang menjadi salahsatu instrumen untuk menyebarkan serta memperkuat hegemoni dominan, yaitu diantaranya adalah media radio (Afandi, 2016). Rahanatha dalam Romli, (2016) menjelaskan pengertian radio adalah teknologi yang digunakan untuk pengiriman sinyal dengan cara modulasi dan radiasi elektronik (gelombang elektromagnetik). Dengan demikian, yang dimaksud dengan istilah radio bukan hanya bentuk fisiknya, tetapi antara bentuk fisik dengan kegiatan radio adalah saling berhubungan dan tidak dapat dipisahkan satu sama lain. Karena itu apabila pengertian radio tersebut dipisahkan satu persatu atau pun diperinci secara fisik, maka yang dimaksud dengan radio adalah keseluruhan dari pada pemancar, studio, dan pesawat penerima sekaligus. Radio memiliki keunggulan karena tidak mengenal rintangan geografis, itulah sebabnya berita atau informasi melalui radio dapat diterima dimana saja. Siaran radio dapat diterima atau didengar bukan hanya oleh orang yang berpendidikan tinggi, tetapi juga oleh orang yang berpendidikan rendah (Arifin, 2011).

\section{Televisi}

Dewasa ini media massa menjadi salah satu arus utama sebagai sumber informasi yang mudah di dapat oleh seluruh kalangan di masyarakat. Salah satu bentuk dari media massa yang efektif dan efesien dalam mencapai audiensnya dalam presentase jumlah yang sangat banyak yaitu media televisi (Sinaga, 2018). TerkaitTelevisi pada umumnya cenderung kepada kesimpulan, bahwa medium televisi melebihi kemampuan media massa lainnya dalam mempengaruhi sikap maupun khalayak. Menurut Andi Alimuddin Unde (2014) kelebihan televisi dalam mempengaruhi perilaku khalayak, bercirikan gejala- gejala berikut ini :

1. Bersifat lihat-dengar (Audiovisual)

2. Cepat mencapai khalayak yang relative tidak terbatas jumlahnya

3. Televisi menghimpun dalam dirinya gejala komunikasi radio, film (gambar hidup), komunikasi tertulis, potret diam, serta kode analogik dan kode mediator lainnya

4. Televisi memiliki ciri-ciri personal yang lebih besar dari media massa lainnya, atau menyerupai komunikasi tatap muka.

Ciri-ciri tersebut berkembang pengertian bahwa siaran televisi seakanakan memindahkan realitas kehadapan penonton, dan karena itu penonton seakan-akan terlibat secara langsung atau "hadir sendiri" pada peristiwa tersebut meskipun kejadian dan tempat itu mungkin sangat jauh dari penonton (Unde, 2014).

\section{Metode Penelitian}

Penelitian ini menggunakan tipe penelitian kualitatif, untuk menghasilkan data deskriptif. Riset kualitatif bertujuan untuk menjelaskan fenomena dengan sedalam-dalamnya melalui pengumpulan data sedalam-dalamnya. Riset ini tidak mengutamakan besarnya populasi atau sampling bahkan populasi atau sampling sangat terbatas (Kriyantono, 2006). Dasar penelitian adalah analisa kerja dan aktivitas. Penelitian ditujukan untuk menyelidiki secara terperinci aktivitas dan pekerjaan manusia, dan hasil penelitian tersebut dapat memberikan rekomendasirekomendasi untuk keperluan masa yang akan datang (Nazir, 1998). Penelitian ini dilakukan di Komisi Penyiaran Indonesia Daerah Sulawesi Tengah, dengan melakukan pengumpulan data berupa observasi, wawancara mendalam dan dokumentasi. Teknik analisis data yang digunakan dalam penelitian ini adalah Miles dan Huberman dalam Sugiyono (2007), analisis data ini terdiri dari reduksi 
data, penyajian data, dan penarikan kesimpulan.

\section{Hasil Penelitian Dan Pembahasan}

Berkaitan dengan fungsinya, KPI memiliki kewenangan (otoritas) dalam hal menyusun dan mengawasi berbagai peraturan penyiaran yang menghubungkan antara lembaga penyiaran, pemerintah, dan masyarakat. Pengaturan ini mencakup semua proses kegiatan penyiaran, mulai dari tahap pendirian, operasionalisasi, pertanggung jawaban, dan evaluasi. Karena spektrum pengaturan yang saling berkaitan, membuat KPI harus berkoordinasi dengan pemerintah dan lembaga negara lainnya; misalnya, terkait dengan kewenangan yudisial karena terjadinya pelanggaran oleh UU Penyiaran dikategorikan sebagai tindak pidana. Selain itu, KPI juga berhubungan dengan masyarakat dalam menampung dan menindaklanjuti segenap bentuk apresiasi mereka terhadap lembaga penyiaran maupun terhadap dunia penyiaran pada umumnya (Khuzaini, 2017).

Pelaksanaan pengawasan isi siaran kepada lembaga penyiaran di Sulawesi Tengah yang teletak dibeberapa kabupaten dan kota yang ada di Sulawesi Tengah oleh anggota KPID Sulawesi Tengah, berdasarkan data yang telah didapatkan sebelumnya maka peran dan fungsi KPID Sulawesi Tengah dalam melakukan pengawasan terhadap penyiaran di Kota Palu, yaitu:

\section{Sebagai pendeteksi konten siaran (Detector)}

Detector ialah orang yang ditugaskan untuk mengetahui tentang apa yang ditampilkan oleh lembaga penyiaran sesuai dengan apa yang seharusnya ditampilkan dalam hal ini staf pemantau KPID Sulawesi Tengah yang bertugas untuk mengawasi apakah konten isi siaran yang ditampilkan Lembaga Penyiaran yang sedang ditayangkan sesuai dengan kode etik penyiaran seperti tayangan berbau seksual, kekerasan, berkata kasar, hingga SARA. Maksud dari pengawasan ini ialah agar kemudian lembaga-lembaga penyiaran tidak seenaknya saja menyiarakan sesuatu, dengan membuat mereka merasa bahwa mereka sedang dipantau, sehingga hal-hal yang bisa mengakibatkan pelanggaran bisa diminimalisir.

Pengawasan ini merupakan salah satu pengendalian dari KPID Sulawesi Tengah agar supaya kesalahan-kesalahan yang pernah ditampilkan tidak diulangi kembali oleh Lembaga Penyiaran tersebut atau Lembaga penyiaran lainnya, selain dari staf pemantau KPID, yang peneliti dapatkan juga bahwa sebenarnya pengawasan konten isi siaran juga tidak hanya dilakukan oleh pihak KPID, tapi juga pihak media dan seluruh elemen masyarakat ikut terlibat langsung, karena tujuan ditayangkannya sebuah siaran agar masyarakat bisa mendapatkan informasi dan hiburan yang sesuai dengan peraturan yang ada, maka dari itu KPID Sulawesi Tengah juga menerima aduan dari masyarakat terkait dengan konten isi siaran mulai dari laporan langsung hingga komentar- komentar di sosial media mereka sesuai dengan Undang-undang Nomor 32 Tahun 2002 pasal 50 tentang penyiaran bahwa:

1. KPI wajib menerima aduan dari setiap orang atau kelompok orang yang mengetahui adanya pelanggaran pedoman perilaku penyiaran.

2. KPI wajib menindaklanjuti aduan resmi mengenai hal-hal yang bersifat mendasar.

3. KPI wajib menyampaikan secara tertulis hasil evaluasi dan penilaian kepada pihak yang mengajukan aduan dan lembaga penyiaran terkait. 
Dari penjelasan diatas dapat dikatakan bahwa masyarakat berhak mendapatkan siaran baik dan sehat sesuai dengan pedoman perilaku penyiaran, sehingga masyarakat bisa mengadukan apabila ternyata terdapat konten isi siaran yang dirasa kurang mendidik atau tidak sesuai dengan norma atau peraturan yang ada, dan juga lembaga penyiaran harus ikut berperan menjaga ketertiban umum, dengan tidak menayangkan siaran yang tidak sesuai dengan peraturan yang berlaku sehingga tidak menyebabkan terjadinya perpecahbelaan, Sebaliknya lembaga penyiaran baiknya menampilkan siaran yang mampu menyatukan bangsa dengan menayangkan siaran-siaran yang sehat dan baik. Pengawasan yang dilakukan KPID Sulawesi Tengah sangat tersusun dengan baik mulai dari pemantauan konten isi siaran, menganalisa aduan yang masuk, hingga penyerahan temuan pelanggaran ke komisioner, dari hasil temuan tersebut kemudian pihak komisioner menganalisa potensi pelanggaran sesuai dengan pedoman yang ada.

Walaupun KPID Sulawesi Tengah melakukan pemantauan siaran setiap hari akan tetapi masih ada saja pelanggaranpelanggaran yang ditemukan, maka dari itu pentingnya pengawasan KPID guna membuat lembaga-lembaga penyiaran sadar akan tayangan mereka, tetapi didalam KPID sendiri pemantauan yang dilakukan masih kurang karena untuk pemantauan siaran televisi KPID Sulawesi Tengah tidak melakukan pemantauan secara langsung tetapi mereka menilai siaran tersebut dengan cara memutar rekaman siaran televisi pada besok harinya kemudian mereka mencatat pelanggaran-pelanggaran apa saja yang dilanggar, walaupun demikian pemantauan konten siaran di KPID Sulawesi Tengah masih jauh dari kata sempurna karena diakhir tahun 2018 tepatnya pada tanggal 28 september 2018 banyak dari peralatan KPID Sulawesi tengah yang mengalami kerusakan yang menyebabkan berkurangnya kinerja KPID dalam mengawasi konten siaran terutama pada stasiun Televisi yang hingga pada saat tulisan ini dibuat KPID Sulawesi Tengah masih belum melakukan pemantauan langsung terhadap konten siaran pada Televisi, walaupun mereka merekam konten siaran pada Televisi akan tetapi dari apa yang peneliti temukan dilapangan bahwa masih kurangnya kinerja KPID karena untuk orang yang menyaksikan rekaman siaran Televisi hanya berjumlah 1 orang yaitu staf ahli KPID tugasnya tidak hanya menyaksikan rekaman tersebut tetapi juga dia memberikan pada data pantauan dari staf tenaga pemantau KPI.

\section{Sebagai seleksi konten isi siaran (Selector)}

Seleksi konten isi siaran ialah berupa alat atau tuntunan yang digunakan KPID Sulawesi Tengah untuk menilai tentang apa yang ditampilkan lembaga penyiaran betul telah sesuai dengan kode etik penyiaran yang berlaku di Indonesia, karena dengan semakin dimudahkannya akses terhadap konten siaran, maka perlu adanya pedoman yang mengatur sebuah tayangan, oleh karena itu KPID Sulawesi Tengah sebagai lembaga yang mengawasi konten siaran yang ditempatkan di Provinsi Sulawesi Tengah perlu menjamin bahwa masyarakat mendapatkan siaran yang baik dan benar sesuai dengan etika penyiaran yang ada di Indonesia, seperti Pedoman Perilaku Penyiaran dan Standar Program Siaran (P3SPS) yang digunakan untuk menyeleksi Konten siaran yang ditayangkan. Dengan berpatokan pada P3SPS, Pengawasan yang dilakukan KPID Sulawesi Tengah bertujuan untuk supaya Lembaga-lembaga Penyiaran agar kiranya dapat menjalankan fungsinya dengan menayangkan siaran yang mendidik, memberikan informasi yang 
benar dengan tidak menambahkan ataupun mengurangi informasi yang didapatkan, serta sebagai perekat dan kontrol sosial.

Maksudnya ialah dalam melakukan tayangan siaran lembaga penyiaran harus berpatokan dengan P3SPS sebagai kontrol lembaga penyiaran dalam menyiapkan hingga menayangkan siaran, selain dengan lembaga penyiaran, KPID Sulawesi Tengah dalam mengawasi isi siaran menggunakan P3SPS sebagai pedoman untuk melakukan pengawasan, artinya KPID Sulawesi Tengah dalam melakukan pengawasan tidak sematamata langsung mengatakan bahwasannya sebuah siaran yang ditayangkan melakukan pelanggaran, akan tetapi pelanggaran yang didapatkan betul-betul telah dianalisa pemantauan dengan menggunakan P3SPS sebagai alat atau pedoman untuk mengetahui bahwa siaran yang ditayangkan terindikasi melakukan pelanggaran atau tidak.

$$
\text { Adaupun Dasar Hukum }
$$

pengawasan KPID Sulawesi Tengah terhadap isi siaran antara lain sebagai berikut:

1. Undang-undang Nomor 32 Tahun 2002 tentang Penyiaran Pasal 6 disebutkan bahwa Negara menguasai spektrum frekuensi radio yang digunakan untuk penyelenggaraan penyiaran guna sebesar-besarnya kemakmuran rakyat.

2. Undang-undang Nomor 32 Tahun 2002 tentang Penyiaran Pasal 8 ayat huruf c menyebutkan bahwa KPI/KPID memiliki wewenang mengawasi pelaksanaan Peraturan dan Pedoman Perilaku Penyiaran serta Standar Program Siaran.

3. Undang-undang Nomor 32 Tahun 2002 tentang Penyiaran Pasal 8 ayat huruf a menyebutkan bahwa KPI/KPID memiliki kewajiban menjamin masyarakat untuk memperoleh informasi yang layak dan benar sesuai dengan hak asasi masnusia.

Dalam melakukan pengawasan, KPID Sulawesi Tengah sebagaimana yang diatur dalam Undang-Undang No. 32 tentang penyiaran ialah pengawasan yang berpedoman pada standarisasi yang ditetapkan KPI pusat yaitu Pedoman Perilaku Penyiaran dan Standar Program Siaran (P3PS).

\section{Kegiatan untuk mengubah perilaku agar sesuai dengan P3SPS}

Kegiatan yang dilakukan oleh KPID Sulawesi Tengah untuk memperbaiki kesalahan yang telah dilakukan oleh lembaga penyiaran, biasanya dengan melakukan pembinaan terhadap lembaga penyiaran yang melakukan pelanggaran guna mengingatkan lembaga penyiaran tersebut untuk selalu menerapkan pedoman yang berlaku yaitu P3SPS. KPID Sulawesi Tengah Ketika menerima laporan terkait dengan pelanggaran yang didapatkan entah dari laporan masyarakat ataupun temuan langsung dari tenaga pemantau, langsung menganalisa temuan tersebut melalui tim analisis mereka, kemudian dibawa kerapat yang dilakukan KPI Sulawesi Tengah yaitu rapat pleno untuk membahas masalah temuan pelanggaran yang didapatkan oleh tenaga pemantau ataupun aduan dari masyarakat, dari hasil rapat itulah kemudian KPID Sulawesi Tengah mengambil sikap, mengambil sikap disini bahwa Lembaga penyiaran yang didapatkan melakukan pelanggaran akan diberikan sanksi dan pembinaan. Sebelum memberikan sanksi pihak KPID Sulawesi tengah memanggil Lembaga penyiaran yang melakukan pelanggaran kemudian dimintai keterangan atau klarifikasi terkait dengan pelanggaran yang dilakukan.

Adapun sanksi yang diberikan biasanya dalam bentuk teguran lisan, apabila masih melakukan melakukan 
pelanggaran yang sama kemudian diberikan sanksi berupa surat teguran, dan apabila masih tetap melakukannya KPID bisa saja melakukan teguran keras hingga pencabutan izin siaran, walaupun Lembaga penyiaran di kota Palu tidak pernah sampai mendapatkan teguran keras dari KPID Sulawesi Tengah. KPID Sulawesi Tengah menjalankan perannya dengan sungguh- sungguh sesuai dengan P3SPS yang merupakan Pedoman yang digunakan KPID dalam menjalankan peran dan fungsinya.Berdasarkan penjelasan diatas peran KPID Sulawesi tengah dalam mengubah perilaku Lembaga Penyiaran di kota Palu dengan cara memberikan pembinaan ataupun teguran dengan upaya agar Lembaga Penyiaran yang ada di kota Palu dapat menjaga kualitas tayangannya. Kegiatan ini menguruiakan kegiatan yang dilakukan oleh KPID Sulawesi Tengah sesudah didapatkannya kesalahan atau pelangaranpelanggaran yang dilakukan Lembaga Penyiaran guna untuk memperbaiki atau mengubah siaran yang akan ditayangkan nanti agar dalam pelaksanaanya tidak melanggar dari pedoman yang ada yaitu P3SPS.

\section{Komunikasi dari KPID Sulawesi Tengah}

KPID Sulawesi Tengah mempunyai tugas dan kewajiban yang tertuang dalam Undang-undang penyiaran pasal (8) ayat (3) yaitu : menjamin masyarakat untuk memperoleh informasi yang layak dan benar sesuai dengan hak asasi manusia; ikut membantu pengaturan instruktur bidang penyiaran; ikut membantu iklim persaingan yang sehat antar lembaga penyiaran dan industri terkait; memelihara tatanan informasi nasional yang adil, merata, dan seimbang; menampung, meneliti, dan menindaklanjuti aduan dan sanggahan, serta kritik dan apresiasi masyarakat terhadap penyelenggaraan penyiaran; dan menyusun perencanaan pengembangan sumber daya manusia yang menjamin profesionalitas di bidang penyiaran. Dalam menjalankan tugas dan kewajiban tersebut KPID Sulawesi Tengah berkoordinasi dengan pemerintah dan lembaga-lembaga lain guna untuk mengatur penyiaran yang saling berkaitan. KPID Sulawesi Tengah bersosialisasi dengan masyarakat guna untuk memberikan pemahaman kepada mereka tentang lembaga penyiaran maupun dunia penyiaran pada umumnya.

KPID Sulawesi Tengah biasanya melakukan komunikasi dengan masyarakat yang disebut literasi media kegiatan ini dimaksudkan agar kiranya masyarakat dapat mengetahui terkait dengan tayangan-tayangan yang sebenarnya tidak boleh disiarkan oleh lembaga penyiaran baik televisi maupun radio, selain itu juga KPID Sulawesi Tengah menerima keluhan masyarakat terkait dengan konten siaran mulai dari laporan langsung, surat laporan, hingga keluhan masyarakat di sosial media agar keresahan-keresahan yang dirasakan masyarakat dapat tersampaikan guna untuk penyiaran yang sehat kedepannya. Kegiatan komunikasi yang dilakukan KPID Sulawesi Tengah biasanya juga muncul di lembaga-lembaga penyiaran televisi maupun radio untuk memberitahukan kepada masyarakat terkait dengan siaran yang baik dan sehat adalah siaran yang berpegang pada Pedoman Perilaku Penyiaran dan Standar Program Siaran.

Dilihat dari penjelasan-penjelasan diatas terkait dengan peran dan fungsi pengawasan kebijakan siaran yang dilakukan oleh KPID Sulawesi Tengah dengan berpatokan pada P3SPS yang merupakan perturan yang berisi sesuatu yang boleh dan tidak boleh ditayangkan dalam suatu program siaran. Apabila dalam sebuah tayangan terjadi sebuah kesalahan atas P3SPS, maka lembaga 
penyiaran yang menyiarkan tayangan tersebut bertanggung jawab akan pelanggaran yang dilakukannya. Sebagai contoh jika sebuah Lembaga Penyiaran menayangkan siaran yang berbau SARA dan dapat menimbulkan perpecah belaan maka Lembaga Penyiaran tersebut melakukan pelanggaran terhadap Pedoman Perilaku Penyiaran dan Standar Progran Siaran.

Pelanggaran-pelanggaran yang dilakukan oleh lembaga penyiaran televisi maupun radio akan dicatat dan direkam tayangannya oleh KPID Sulawesi Tengah dan dari catatan dan rekaman itu kemudian akan dijadikan sebagai bahan pertimbangan oleh KPID Sulawesi Tengah dalam memberikan keputusankeputusan yang menyangkut dengan lembaga penyiaran tersebut.

\section{Kesimpulan}

Dalam pembuatan hingga penayangan siaran radio maupun Televisi tentunya tidak lepas dari peraturan yang mengatur tentang sebuah tayangan agar masyarakat yang menyaksikan siaran mendapatkan informasi yang baik dan sehat sesuai dengan pedoman yang ditetapkan oleh pemerintah yaitu P3SPS, oleh karena itu perlu adanya lembaga yang mengawasi bagaimana sebuah tayangan itu disiarkan dalam hal ini KPID yang merupakan lembaga yang berperan dalam mengawasi tayangan siaran yang ada di Sulawesi Tengah.

Berdasarkan yang telah diuraikan sebelumnya, serta berdasarkan hasil observasi dan wawancara peneliti di Komisi Penyiaran Indonesia Daerah Sulawesi Tengah, peneliti mendapatkan jawaban atas rumusan masalah dalam skripsi ini, maka peneliti dapat mengambil kesimpulan sebagai berikut.

1. Peran dan fungsi pengawasan KPID Sulawesi Tengah terhadap kebijakan siaran di kota Palu. Komisi Penyiaran Indonesia Sulawesi Tengah melakukan peran dan fungsinya dalam mengawasi proses siaran di kota palu dengan cara sebagai berikut: (1) bekerja sama dengan KPU dan BAWASLU pengawasan siaran kampanye, dan kepolisan sebagai instansi dalam penindakan lebih lanjut terkait dengan pelanggaran yang dilakukan. menggunakan P3SPS sebagai Rule atau pedoman dalam melakukan pengawasan untuk menilai pelanggaran-pelanggaran yang dilakukan Lembaga Penyiaran di kota palu. (3) melakukan pengawasan langsung lembaga Penyiaran yang disiarkan. (4) menerima keluhankeluhan dari masyarakat baik langsung, menggunakan surat laporan ataupun dengan komentar-komentar di sosial media.

2. Tindak lanjut pengawasan terhadap radio dan sanksi bagi program yang melakukan pelanggaran di kota palu Adapun dari tindak lanjut pengawasan dan sanksi yang diberikan bagi program yang melanggar siaran di kota Palu sebagai berikut : (1) data pelanggaran yang didapatkan oleh tenaga pemantau kemudian dianalisis oleh tim analisis KPID, dari hasil Analisa tersebut kemudian komisioner bidang isi siaran mengundang seluruh komisioner yang ada di KPID Sulawesi Tengah dalam rapat pleno yang dilakukan oleh KPID guna untuk membicarakan terkait dengan pelanggaran yang didapatkan oleh staf tenaga pemantau KPID, dari hasil rapat itu kemudian ditentukan pelanggaran dan sanksi apa yang akan diberikan oleh KPID kepada Lembaga penyiaran yang melakukan pelanggaran, (2) setelah penentuan pelanggaran, KPID Sulawesi Tengah memanggil Lembaga penyiaran terkait guna untuk dimintai keterangan dan diperdengarkan pelanggaran yang dilakukan (3) KPID Sulawesi Tengah memberikan sanksi berupa teguran 
langsung terkait dengan pelanggaran yang dilakukan.

\section{Referensi}

Afandi, A. (2016). Peran Komisi

Penyiaran Indonesia Daerah (

KIPD ) Provinsi Banten dalam pengewasan Isis siaran (Studi Di KIPD Provinsi Banten).

Arifin, A. (2011). Sistem Komunikasi Indonesia. PT Remaja Rosdakarya.

Eli Fatmala. (2018). Sistem Pengawasam KPID Jawa Tengah Terhadap Siaran Dakwah Televisi Lokal Semarang Tahun 2014 - 2016.

Judhariksawan. (2010). Hukum Penyiaran. Rajagrafindo.

Jueita, R. (2013). Peran Komisi Penyiaran Indonesia ( Kpi) Dalam Mengawasi Tayangan Sinetron.

Khuzaini, A. A. (2017). Pengaruh Transaksi Online Shopping Dan Kepercayaan Konsumen Terhadap Kepuasan Konsumen Pada ECommerce. Jurnal Ilmu Dan Riset Manajemen, 6(7).

Kriyantono, R. (2006). Teknis Praktis Riset Komunikasi. PT Kencana Perdana.

Luaylik, N. F. (2018). Implementasi Fungsi Pengawasan Penyiaran Program (Vol. 8).

Morrisan. (2008). Manajemen Media Penyiaran: Strategi Mengelola Radio dan Televisi. Prenadamedia Group.

Nazir. (1998). Metode Penelitian. Ghalia Indonesia.

Prasetyo, F. E. (2017). Peran Komunikasi Dalam Mengoptimalkan Komisi Penyiaran Indonesia Daerah ( Kpid ) Provinsi Kalimantan Timur Dalam Melakukan. Ilmu Komunikasi, 5(4), 2.

Rolando. (2018). PERAN KOMISI

PENYIARAN INDONESIA DAERAH PROVINSI LAMPUNG
DALAM PROSES PENGAWASAN

SIARAN TV LOKAL (Pengawasan Isi Siaran Periode Tayang Pada Tahun 2016 ) LOKAL (

Pengawasan Isi Siaran Periode Tayang Pada Tahun 2016).

Samad, A. (2014). Peran Pemerintah Daerah Dalam Pemberdayaan Masyarakat Petani Kakao Di Desa Kayuangin Kecamatan Malunda Kabupaten Majene. Pemerintahan, IV (1), 2.

Sinaga, B. F. (2018). Peran Komisi Penyiaran Indonesia (Kpi) Pusat Dalam Melakukan Pengawasan Isi Siaran Pilkada 2018 (Studi Deskriptif Pada Bidang Pengawasan Isi Siaran Kpi Di Televisi).

Unde, A. A. (2014). Televisi dan Masyarakat Pluralistik. Prenadamedia Group. 